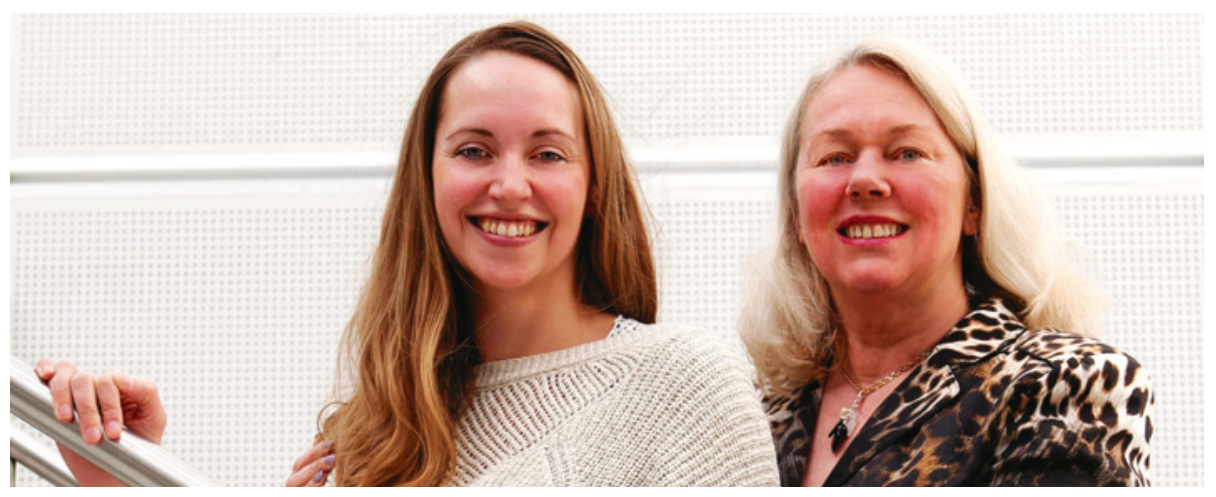

Fra venstre: Førsteforfatter Gry Syverstad og sisteforfatter Reidun Torp. Foto: Gunnar F. Lothe, Institutt for medisinske basalfag

MIN FØRSTE PUBLIKASJON

\title{
Alzheimer-forandringer hos mus varierer mye
}

Transgene mus brukes mye i prekliniske studier av Alzheimers sykdom. Utbredelsen av karakteristiske hjerneforandringer hos musene varierer, noe som kan gjøre det vanskelig å sammenlikne resultater fra ulike studier.

Forskere ved Institutt for medisinske basalfag og Farmakologisk institutt ved Universitetet i Oslo har i mange år benyttet musemodellen tg-ArcSwe, som har to mutasjoner i $A P P$-genet, til studier av molekylære mekanismer involvert i Alzheimers sykdom. Disse musene er kjent for å uttrykke $\beta$-amyloide plakk i bestemte områder av hjernen, i tillegg har de vaskulære deponeringer langs cerebrale kar.

For å kunne bruke modellen til å kartlegge sykdomsmekanismer og vurdere mulige nye behandlingsmetoder, må man ha gode data om hvor i hjernen Alzheimer-relaterte plakk forekommer og i hvilken grad mengden av slike plakk varierer mellom dyr. Forskerlinjestudent Gry Syverstad og hennes medarbeidere har benyttet immunhistokjemi og kvantitativ bildeanalyse til å visualisere og måle plakkvariasjonen i gamle tg-ArcSwemus (1).

Studien viser at amyloide plakk alltid forekommer i hjernebarken, hippocampus og thalamus, mens tilstedeværelsen av plakk er mer variabel i andre hjerneregioner. Den gjennomsnittlige amyloiddeponeringen hos dyrene var nokså lik i både hjernebark og hippocampus, med variasjonskoeffisienter mellom dyrene i gruppen på henholdsvis $22 \%$ og $25 \%$.

- Variasjonen i plakkdeponering må tas i betraktning når dyremodeller brukes til eksperimentelle intervensjonsstudier, sier Gry Syverstad. - For å kunne måle en behandlingseffekt på $25 \%$ kreves et vesentlig høyere antall dyr enn det som vanligvis blir benyttet i slike studier, sier hun.

For å bidra til åpenhet i feltet og gi kolle- ger anledning til å vurdere de patologiske avvikene i detalj har forskergruppen laget et nettbasert atlas (2). Denne nettsiden gir tilgang til serier av mikroskopiske bilder som viser distribusjon og morfologi av plakk i detalj gjennom hele hjernen. Nettsiden er fritt tilgjengelig for alle interesserte forskere.

\section{Forskergruppen}

Studien er et samarbeid mellom forskere ved Institutt for medisinske basalfag og Farmakologisk institutt ved Universitetet i Oslo. Lars N.G. Nilsson ved Farmakologisk institutt etablerte tg-ArcSwe-modellen for Alzheimers sykdom mens han arbeidet ved Uppsala Universitet i Sverige.

Dette er den første vitenskapelige publikasjonen til Gry Helen Enger Syverstad, som deler førsteforfatterskapet på artikkelen med Sveinung Lillehaug. Syverstad er medisin- og forskerlinjestudent ved Universitetet i Oslo og veiledes av Reidun Torp. Andre medforfattere er Jan G. Bjaalie og Trygve B. Leergaard fra forskergruppen Nevrale systemer ved Institutt for medisinske basalfag, som utvikler digitale hjerneatlas og bruker avanserte bildedannende teknikker i sine studier av hjernens oppbygning og arkitektur, nettverk og gener.

\section{Kari Tveito}

Tidsskriftet

Litteratur

1. Lillehaug S, Syverstad GH, Nilsson LN et al. Brainwide distribution and variance of amyloid-beta deposits in tg-ArcSwe mice. Neurobiol Aging 2014: 35: $556-64$.

2. Rodent Brain WorkBench. www.rbwb.org (28.4.2014).
Ordforklaringer:

APP-genet: APP er en forkortelse for «amyloid precursor protein», og APP-genet befinner seg på kromosom 21. Mutasjoner i dette genet har vist seg å være relevante for utvikling av Alzheimers sykdom, ettersom APP-proteinet kan brytes ned til $\beta$-amyloid protein.

$\beta$-amyloide plakk: Ved Alzheimers sykdom avleires plakk med $\beta$-amyloid protein i ekstracellulært vev i hjernen.

Kvantitativ bildeanalyse: Bildeanalyse basert på bruk av høyoppløselige bilder og analyseprogrammer. Man definerer den region som er av interesse (region of interest; ROI) ut fra anatomiske kriterier. Bildene konverteres til svart-hvitt og mengden amyloide plakk måles.
Artikkelen ble publisert i Neurobiology of Aging, som er rangert som det fremste tidsskriftet innenfor geriatri og gerontologi, i mars 2014. 